\title{
Perspectives about implementation of colour codes on maps accessible to blind people
}

\author{
Niédja Sodré de Araújo ${ }^{\mathrm{a},}$, , Luciene Stamato Delazari ${ }^{\mathrm{b}}$, Amanda Pereira Antunes ${ }^{\mathrm{c}}$, Andrea Faria \\ Andrade ${ }^{\mathrm{d}}$ \\ a,b,c,d Graduate Program in Geodetic Sciences (PPGCG), Federal University of Paraná (UFPR), Curitiba - PR, Brazil, \\ a, ${ }^{*}$ niedja.geo@gmail.com, ${ }^{b}$ luciene@ufpr.br, ${ }^{c}$ amandapereiraantunes@gmail.com,dandreafaria@ufpr.br \\ * Corresponding author
}

\begin{abstract}
:
The development of tactile colour codes or tactile symbols for colours aims to communicate the visual variable colour to blind people. Initially these colour codes were thought to meet the need for autonomous clothing in the absence of a sense of sight and for learning the theory of colours. The objective of this research is to investigate the perspectives of the professionals in geoinformation about the viability of implementing colour codes on thematic tactile maps using only the graphic primitive area. So, geoinformation professionals were invited to express their perspectives about ten colour code systems during and after the "I Workshop Usability 4 All", realized during the "XI Brazilian Colloquium on Geodetic Sciences", Brazil, 2020. The results indicated that there is no consensus between which system is more appropriate for experimentation in tactile maps. However, Feelipa Color and See Color were the systems evaluated with the greatest potential because six participants preferred the first and five preferred the second, associated with the fact that both systems were classified as reasonable and potentially viable for implementation in the primitive area, considering the aspects of Drawing, Dimensions and Intuitiveness.
\end{abstract}

Keywords: cartographic design, symbology, graphic variable, see color, tactile map

The full paper of the conference presentation is published in the International Journal of Cartography: Niédja Sodré de Araújo, Luciene Stamato Delazari, Amanda Pereira Antunes \& Andrea Faria Andrade (2021) Perspectives about implementation of colour codes on maps accessible to blind people,

International Journal of Cartography, https://doi.org/10.1080/23729333.2021.1980938 